\title{
Phenotypic and Genotypic Characterization of
} Clostridium perfringens Isolated from Cattle Meat Mahmoud E. El-Sayed, Islam Z. Mohamed, and *Islam M. Khalifa

Department of Bacteriology, Immunology and Mycology, Faculty of Veterinary Medicine, Suez Canal University. *Animal Health Research Institute, Dokki, Giza

\begin{abstract}
The existence of Clostridium perfringens in cattle meat has a public health importance. This study was aimed to investigate the Clostridia perfringens prevalence in cattle meat. Forty meat samples from fore and hind quarter ( 20 for each) were randomly collected from abattoirs and butcher's markets at south Sinai province. The collected samples were subjected to the bacteriological examination; moreover, the total $C$. perfringens count from examined meat samples was $2 \times 10^{3}$ C.F.U./ g; in addition, the prevalence of $C$. perfringens was $30 \%$ in cattle meat samples. Molecular typing using multiplex PCR for detection of the major toxin genes of $C$. perfringens revealed that positive gene detection at $324 \mathrm{bp}$ for $C$. perfringens type A. Also enterotoxin virulent gene was detected at $485 \mathrm{bp} \mathrm{C}$. perfringens is considered one of the main spoilage organisms of meat leading to contaminations of great amount of decomposed meat, which ending with economic losses; bad hygienic conditions in slaughterhouses are the main cause for meat contamination with Clostridium species, since the gastrointestinal tract of slaughtered animals is their natural habitat, the abattoir processing represent a great source for meat surface contamination by these pathogens.
\end{abstract}

Keywords: $C$. perfringens, cattle meat, PCR, pathogens.

\section{Introduction}

Meat is an excellent source of high quality protein and rich in minerals and vitamins which are essential for human health, power and vitality. Meat may affect the public health due to their contamination with spoilage microorganisms which are responsible for objectionable changes as well as the presence of pathogenic organisms which may lead to either food infection or food intoxication (Libby, 1975; Hanninen, 1980 and FAO/WHO, 1983). Microbiological quality of fresh meat has been receiving 
attention all over the world due to the occurrence of significant outbreaks of foodborne illness affecting consumers. Quality maintenance is important not only for consumer health protection but also to assure uniformity in fresh meat shelflife, (Widders, 1995). Meat represented the main source of proteins and essential amino acids. So, it considered a highly favorable environment for the growth of pathogenic bacteria. The microbiological contamination of carcasses occurs mainly during processing and handling, such as skinning, evisceration, storage and distribution at slaughter houses and retail establishments (Gill, 1998 and Abdalla et al., 2009). Many public health hazards were detected due to presence of anaerobic Clostridia. Their spores enable it to survive the relatively high temperature (Barnes, 1985). C. perfringens as a food poisoning organism has a human health hazards. Due to the consumption of meat and meat products, most of foodborne diseases caused by $C$. perfringens occurred (Lynch et al. 2006; Wahl et al. 2013).

The abattoir process is considered the great source of meat surface contamination by C. perfringens organisms either internally from animal after slaughtering as postmorte $\mathrm{m}$ invasion from gastrointestinal tract or externally from contaminated hands, skin of animals, water, soil and processing equipment's. Illness and death caused by foodborne pathogens in developing countries need billions of dollars for medical care and social awareness (Fratmico et al., 2005).

The control and/or prophylaxis for food poisoning outbreaks associated with meat consumption depends mainly on detecting the causative agents in carcasses, eliminating them to ensure food safety and to protect public health from microbial contamination of food (Al Khaldi et al. 2004 and Albini et al. 2008).

The current preliminary study was aimed to investigate the prevalence, total count and molecular characterization of $C$. perfringens in cattle meat.

Mate rial and Methods

1- Collection of samples:

40 meat samples were collected randomly from abattoirs and butcher's markets at South sinai province. Samples were collected separately in sterile plastic bags, and then were labeled and given serial numbers. They were preserved in an Ice box and transferred quickly to the laboratory with minimum of delay for anaerobic bacteriological examination according to Cruickshank et al., (1975). 
2-Processing of collected samples:

a) Preparation of homogenate (ICMSF. 1978).

Twenty-five grams of each sample were removed aseptically using a sterile forceps and scissors from different points of the sample then placed in sterile polyethylene bag, then adding $225 \mathrm{ml}$ of sterile peptone water $0.1 \%$ aseptically; the content was homogenized in a stomacher (MPW.302 Poland) for one minute to provide a dilution of $10^{-1}$ Such homogenate was used for all bacterial investigations.

b) Preparation of serial dilutions:

From the prepared homogenate; 1/10 dilution; $1 \mathrm{ml}$ was taken by a sterile pippete and mixed with $9 \mathrm{ml}$ sterile peptone water $0.1 \%$ in a sterile test tube and was shaken well using a test tube shaker to made a dilution of $1 / 100$ using a new sterile pippete $1 \mathrm{ml}$ was transferred from $1 / 100$ dilution to next tube for making a dilution of 1/1000; the process repeated till dilution of $10^{-5}$.

3-Total $C$. perfringens count:

The method recommended by ICMSF (1978) for enumeration of $C$. perfringens in meat was done.

From each prepared dilution 0.1 $\mathrm{ml}$ was pipetted into the center of each plate of $C$. perfringens selected media (oxoid) which was used for enumeration of the total viable cell count of $C$. perfringens in meat and meat products. Aseptically, the counts of one vial of each Perfringens agar (OPSP) supplements A and B oxoid (SR 76 and SR77) which had been dehydrated by the addition of $2 \mathrm{ml}$ of sterile distilled water were added, mixed well and poured into sterile dishes.

Perfringens (OPSP) selective supplement A oxoid (Code SRO 76E): A box of freeze- dried selective supplement for the isolation of $C$. perfringens contained 10 vials. Each vial was sufficient to supplement $500 \mathrm{ml}$ of perfringens Agar base, and contained $50 \mathrm{mg}$ of sodium sulpha diazine.

Perfringens (OPSP) selective supplement B oxoid (Code SRO 77E). A box of freeze- dried selective supplement for the isolation of C. Perfringens contained 10 vials. Each vial was sufficient to supplement $500 \mathrm{ml}$ of C. Perfringens Agar Base. The vial contained $0.25 \mathrm{mg}$ of Oleandomycin phosphate, and 5000 IU polymyxin B sulphate to each vial $2 \mathrm{ml}$ of sterile distilled water were aseptically added, and mixed gently to dissolve. Aseptically the vial contents from the supplements A and $\mathrm{B}$ were added to $500 \mathrm{ml}$ of perfringens Agar Base and cooled to $50^{\circ} \mathrm{c}$, mixed well and poured into sterile Petri dishes. After making count on 
perfringens agar media then incubated at $37^{\circ} \mathrm{c}$ for $24 \mathrm{hs}$ in Gas-Pack Anaerobic Jar according to Brewer and Allgeier (1966). OPSP agar plates having black colonies were selected and counted.

4- Is olation of Clostridial organism (ICMSF. 1978):

The surface of each sample was sterilized by using hot spatula and two bean size pieces were obtained from the deeper parts, then inoculated separately into two tubes of freshly prepared, previously boiled and cooled cooked meat medium. One of the two inoculated tubes was heated at $80^{\circ} \mathrm{c}$ for 15 minutes in water bath with a depth of water more than the level of the material in tubes, while the second tube was left unheated. Both tubes were then incubated anaerobically at $37^{\circ} \mathrm{c}$ for $48 \mathrm{hrs}$. A loopful from each unheated tube was streaked onto the surface of $10 \%$ sheep blood agar with neomycin sulphate $(200 \mathrm{mg} / \mathrm{ml})$ for isolation of C. perfringens (Smith and Holdeman. 1968) While, the heated tubes were then streaked on $10 \%$ sheep blood agar plates for isolation of other clostridia. Inoculated plates were immediately incubated anaerobically at $37^{\circ} \mathrm{C}$ for 24 - 48 hrs. After incubation, the anaerobic growth on the blood agar plates was examined macroscopically microscopically. and

Selected suspected colonies were transferred to tubes of freshly boiled and cooled cooked meat medium and incubated anaerobically at $37^{\circ} \mathrm{C}$ for 24 hours to have a pure culture of isolates for further identification.

\section{5- Identification of Clostridial} organism:

Isolates were identified according to Smith and Holdeman (1968), Willis (1977), Macfaddin (1980), Smith and Williams (1984) as the following; Staining, cultural characteristics, Nagler's reaction, and different biochemical reactions.

6- Methods of polymerase chain reaction PCR:

DNA Extraction and purification:

Strains of $C$. perfringens types $\mathrm{A}, \mathrm{B}, \mathrm{C}, \mathrm{D}$ and $\mathrm{E}$ were considered positive while $\mathrm{C}$. septicum, $C$. sordellii, $C$. sporogenes, $C$. leptum and $C$. ramosum were the negative controls. Isolated strains were cultured on blood agar and total DNA was extracted as described by (Sambrook and Russell, 200l). Two or three colonies that grown on blood agar were suspended $350 \mu \mathrm{L}$ of STET buffer $(100 \mathrm{mM}$ Tris-HCl, 10 mM EDTA, $100 \mathrm{mM}$ Nacl, 5\% Triton $^{\circledR} \quad \mathrm{X}-100$ ) in $1.5-\mathrm{mL}$ microtubes. Then, $25 \mu \mathrm{L}$ of lysozyme $(10 \mathrm{mg} / \mathrm{mL})$ was added to each solution and the content was mixed, 
subsequently, the microtubes were placed in a boiling water bath for 40 seconds.

The bacterial lysate was centrifuged at $13000 \mathrm{rpm}$ for 15 minutes at room temperature in a Microfuge ${ }^{\circledR} \quad$ refrigerated microcentrifuge (Beckman Coulter, USA). After that, the supernatant was poured into a fresh microcentrifuge tube and the nucleic acids were precipitated from it by adding 40 $\mu \mathrm{L}$ of $2.5 \mathrm{M}$ sodium acetate $(\mathrm{PH}$ 5.2) and $420 \mu \mathrm{L}$ of isopropanol. Precipitated nucleic acids were recovered by centrifugation at $13000 \mathrm{rpm}$ for ten minutes at 4 ${ }^{\circ} \mathrm{C}$. Next, the supernatant was removed and the pellet of nucleic acid was rinsed with $1 \mathrm{~mL}$ of $70 \%$ elhanol at $4{ }^{\circ} \mathrm{C}$. finally, the pellet was dried and resuspended in $50 \mu \mathrm{L}$ of $\mathrm{TE}$ buffer containing RNase.

PCR amplification (Van Asten et al., 2009):

DNA samples were tested in 50 $\mu \mathrm{l}$, reaction volume in a $0.2 \mathrm{ml}$. eppendorf tube, containing PCR buffer which was composed of: $25 \mu \mathrm{l}$ M. Mix [Cosomo PCR red Master Mix (2x)] willow fort W1020300x), England, $2 \mu \mathrm{l}$ target DNA, $1 \mathrm{ml}$ of each primer (containing $10 \mathrm{P}$ mole $/ \mu \mathrm{l}$ ) and the mixture was completed by water nuclease free to $50 \mu \mathrm{l}$.

Identification of the PCR products by agarose gel electrophoresis:

Agarose gel preparation (Applichem, Germany, GmbH), placement of combs and gel pouring. The gel was run until the bromothymol blue and xylene cyanol had migrated the appropriate distance through the gel ( $2 / 3$ of the gel length), the lid of the gel lank was closed and attached to the power supply. After the electric current was turned off, the lid of the gel was removed and the gel was transferred to trans-illuminator to observe the amplified DNA on the gel in comparison to molecular weight markers. The gel was photographed.

PCR protocol for amplification conditions of PCR products.

\begin{tabular}{|l|c|c|c|c|}
\hline Gene & Stage $\left({ }^{\circ} \mathbf{C}\right)$ & Temp. & Time & $\begin{array}{c}\text { No. of } \\
\text { cycle }\end{array}$ \\
\hline \multirow{3}{*}{\begin{tabular}{l} 
toxin of $\begin{array}{c}\text { of } \\
\text { perfringens }\end{array}$ \\
\cline { 2 - 4 }
\end{tabular}} & Initial denaturation & 94 & 2 & 1 \\
\cline { 2 - 4 } & Denaturation & 94 & $15 \mathrm{sec}$. & \multirow{3}{*}{35} \\
\cline { 2 - 4 } & Annealing & 55 & $30 \mathrm{sec}$. & \\
\cline { 2 - 4 } Cpe & extension & 68 & $1 \mathrm{~min}$. & \\
\cline { 2 - 4 } & Initial denaturation & 95 & $15 \mathrm{~min}$. & \multirow{2}{*}{1} \\
\cline { 2 - 4 } & Denaturation & 94 & $30 \mathrm{sec}$. & \multirow{3}{*}{40} \\
\cline { 2 - 4 } & Annealing & 53 & $90 \mathrm{sec}$. & \\
\cline { 2 - 4 } & extension & 72 & $90 \mathrm{sec}$. & \\
\cline { 2 - 5 } & Final extension & 72 & $10 \mathrm{~min}$ & 1 \\
\hline
\end{tabular}


PCR products were analyzed for the presence of specific fragments of the expected length in a $1.5 \%$ agarose gel electrophoresis stained with Ethidium bromide.

\section{RESULTS}

1-The total count of $C$. perfringens from cattle meat samples:

Table (1): Statistically analytical results of $C$. perfringens count of examined meat samples.

\begin{tabular}{|c|c|c|c|}
\hline Cattle meat samples & \multicolumn{3}{|c|}{ Count C.F.U./g } \\
\cline { 2 - 4 } $\begin{array}{c}\text { No=40 } \\
(20 \text { for each quarter })\end{array}$ & Min. & Max. & Mean \pm S.E. \\
\hline Fore quarter & $1 \times 10$ & $6.4 \times 10^{2}$ & $3.4 \times 10^{2} \pm 1.4 \times 10^{2}$ \\
\hline Hind quarter & $1.7 \times 10^{2}$ & $4.2 \times 10^{3}$ & $1.6 \times 10^{3} \pm 8.3 \times 10^{2}$ \\
\hline
\end{tabular}

2-Phe notypic characteristics of $C$. perfringens

Table (2): Phenotypic Identification of C. perfringens:

\begin{tabular}{|c|c|c|c|c|c|c|c|c|c|c|c|}
\hline Biochemical test & $\begin{array}{l}0 \\
\infty \\
0 \\
\stackrel{\lambda}{\lambda} \\
x\end{array}$ & 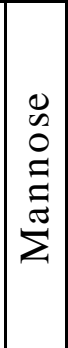 & $\mid \begin{array}{l}0 \\
0 \\
0 \\
\stackrel{\Xi}{\Xi} \\
\Sigma \\
\Sigma\end{array}$ & $\begin{array}{l}n \\
\text { In } \\
\text { I }\end{array}$ & 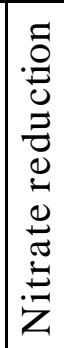 & o & 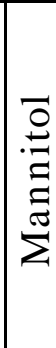 & $\mid \begin{array}{l}0 \\
0 \\
0 \\
0 \\
0 \\
0\end{array}$ & s & & \\
\hline C. perfringens & - & + & + & + & + & - & - & + & - & & \\
\hline
\end{tabular}

$+=$ Positive reaction. $\quad-=$ Negative reaction.

Co

$=$ Central oval.

3-Prevalence of $C$. perfringens in the examined Cattle meat samples:

Table (3): Prevalence of $C$. perfringens in the examined cattle meat samples.

\begin{tabular}{|c|c|c|c|}
\hline \multirow{2}{*}{ Cattle me at samples } & \multicolumn{2}{|c|}{ C.perfringens } \\
\cline { 3 - 4 } & & No. & $\%$ \\
\hline \multirow{2}{*}{$\begin{array}{c}\text { No }=\mathbf{4 0} \\
(20 \text { for each quarter })\end{array}$} & Fore quarter & 5 & 25 \\
\cline { 2 - 4 } & Hind quarter & 7 & 35 \\
\hline
\end{tabular}




\section{4- Mole cular characte rization of $C$. perfringens strains :}

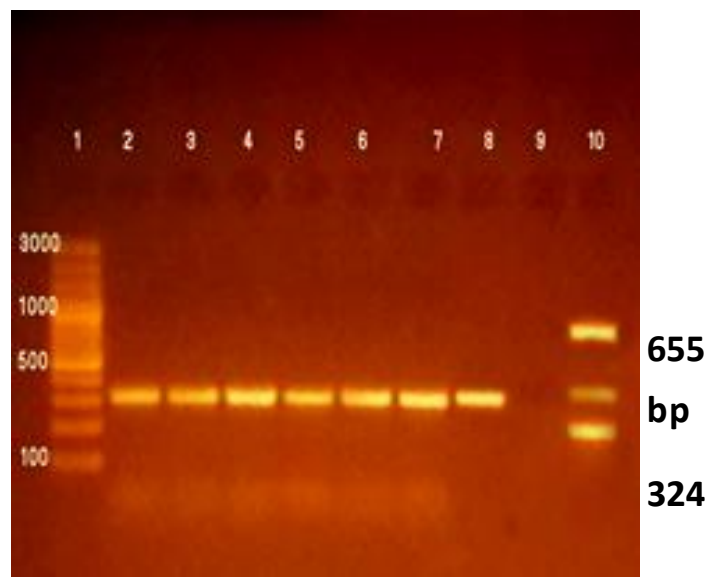

Figure (1): Positive gene amplification for $C$. perfringens type A (cpa) at $324 \mathrm{bp}$.

Lane 1: DNA marker (GeneRuler 100 bp DNA Ladder, Fermentas)

Lane 2-8: Positive C. perfringens type A (cpa) at 324 bp.

Lane 9: Control Negative (mix of various toxin types).

Lane10: Control positive (toxin of C.perfringens of type A)

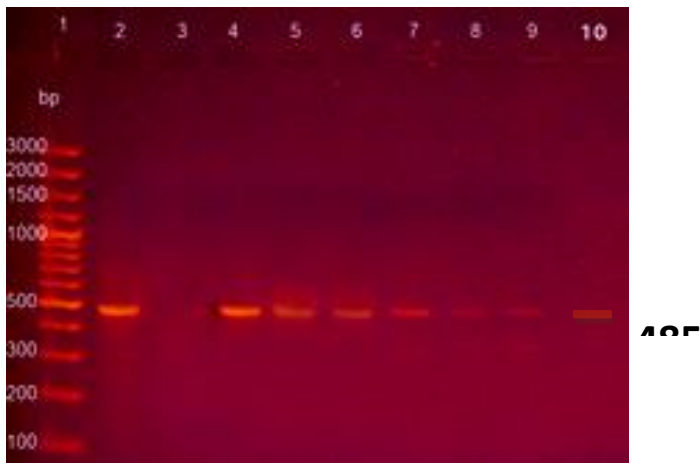

Figure (2): Positive gene amplification of enterotoxin virulent gene (cpe) at $485 \mathrm{bp}$.

Lane 1: DNA marker (GeneRuler 100 bp DNA Ladder, Fermentas)

Lane 2: Control Positive.

Lane 3: Control Negative

Lane 4-10: Positive enterotoxin virulent gene (cpe) at 485 bp.

Discussion

Meat may be contaminated with clostridial spores during the slaughtering process and the following handling. Since $C$. perfringens present in the normal flora of intestinal tract of animals. Contamination of the 
carcass from the intestinal contents, as well as, dust, soil or from workers is virtually unavoidable. In the present work, as illustrated in Table (1), the $C$. perfringens count (C.F.U./g) of the examined samples of cattle meat were $1 \times 10$ to $6.4 \times 10^{2}$ with an average of $3.4 \times 10^{2}+1.4 \times 10^{2}$ obtained from four $(20 \%)$ positive meat samples for fore quarter, $1.7 \times 10^{2}$ to $4.2 \times 10^{3}$ with an average $1.6 \times 10^{3}+8.3 \times 10^{2}$ obtained from five $(25 \%)$ positive meat samples for hind quarter. Hassan (1994) disagreed with this count who detected the $C$. perfringens count of cattle meat samples with a mean value of $1.17 \times 10^{3}++_{-} 0.35$ and $1.90 \times 10^{3}+\ldots .74$ in basateen and moneeb abattoir, respectively. Hedia (2009) mentioned lower prevalence of $C$. perfringens in cattle meat samples for fore quarter with an average of $1.7 \times 10^{2}$ and higher prevalence for hind quarter with an average $2.1 \times 10^{3}$.

The recorded data in table (3) demonstrated the prevalence of $C$. perfringens in the examined cattle meat samples. The percentage of isolation of $C$. perfringens from cattle meat samples were $25 \%$ and $35 \%$ (fore \& hind quarter), respectively. Much higher results were recorded by $\boldsymbol{E} \boldsymbol{l}$ Naenaeey (1989) who isolated C. perfringens from cattle meat with an incidence of $56.5 \%$. Lower results were obtained by Cohen et al., (2006) who isolated the organism from beef meat with an incidence of $4.5 \%$. While Phillips et al. (2008) failed to detect $C$. perfringens from retail ground beef samples. These results were in harmony with the results detected by Hedia (2009) who isolated C. perfringens by percentage $20 \%$ \& $33.4 \%$ from examined cattle raw meat (fore and hind quarter). Much higher result were obtained by Khalid (2013) who isolated C.perfringens from cattle meat samples by percentage $20 \%$. Very high incidence of $C$. perfringens in ground beef samples (96\%) were detected by Guran et al., (2014). Fahim et al. (2017) detected lower incidence of $C$. perfringens in raw beef samples (16\%).

Results of molecular detection of major toxin gene (cpa) using multiplex PCR revealed positive gene amplification at 324 bp for all tested $\mathrm{C}$. perfringens type A figure (1). This result agrees with Nauerby (2003) and Crespo (2007) who applied toxin typing for isolates by PCR and all were found to be type (A). Fisher et al. (2005) disagreed with this result and revealed that, most type $\mathrm{C}$ isolates produce at least three lethal toxins, alpha, beta and perfringolysin $\mathrm{O}$, and several isolates also produced 
beta 2 toxin. Ahsani (2010) used multiplex PCR and isolated C.perfringens type (A) by lower ratio (17.39\%). Mohamed, et al. (2010) used multiplex PCR and revealed that $\mathrm{C}$. perfringens type $\mathrm{A}$ at the rate of $(65 \%)$. This result in harmony with the result obtained by Guran and Oksuztepe (2013) who detected that $97.6 \%$ of $\mathrm{C}$. perfringens isolates carried only $\mathrm{CPa}$ toxin gene (type A) by using multiplex PCR. Nearly similar result obtained by Guran et al. (2014) who used Multiplex PCR and demonstrated that, out of the 262 C. perfringens isolates, 203 (77.4 $\%)$ possessed only the cpa gene (type A). Afshari, Asma; et al. (2015) used multiplex PCR and indicated that $C$. perfringens type $\mathrm{A}$ is the most common type in minced meat. Fayez, et al. (2020) detected $\mathrm{C}$. perfringens type A by lower percentage (75.2\%).

The result in figure (2) revealed the detection of enterotoxin virulent gene (cpe) in all examined C. perfringens isolates by using multiplex PCR. Nasr (2007) reported that enterotoxin gene was detected in all enter toxigenic type $\mathrm{A}$ isolates. In contrast, this result disagrees with Prabhu (2013) who found that all isolates of $C$. perfringens have alpha $(\alpha)$ toxin gene. GamalA. et al. (2018) stated that all toxigenic strains of $C$. perfringens type A $(33,33.7 \%)$ were positive for alpha toxin (сpa) and enterotoxin (cpe) genes. While finding of Yibar et al. (2018) disagree with this result and proved that of the 81 suspicious isolates tested by RTPCR, $22(27.2 \%)$ carried the cpe gene either on the plasmid or chromosome. On the contrary Fayez, et al. (2020) concluded that $C$. perfringens type A with only cpa+ gene was the most prevalent isolated toxin type found in $191(72.9 \%)$ isolates. In conclusion, $C$. perfringens is considered one of the main spoilage organisms of meat leading to contaminations of great amount of decomposed meat, which ending with economic losses. Poor hygienic procedures in slaughterhouses are the main cause for meat contamination with Clostridium species. Since the natural habitat of $C$. perfringens in the gastrointestinal tract of slaughtered animals, the abattoir processing represents a great source for meat surface contamination by $C$. perfringens organisms.

\section{References}

Abdalla, M.A.; Siham, E.; Suliman, Y.V.H. and Alian, A. (2009): Microbial Contamination of sheep Carcasses at El Kadero Slaughterhouse, Khartoum State, 
Sud. J. Vet. Sci., Anim. Husb., 48:1-2.

Afshari, Asma; Jamshidi, A.; Razmyar J. and Rad M. (2015): Molecular typing of Clostridium perfringens isolated from minced meat. Number: 1 Volume:7: 32-39. (Winter \& spring) 2015.

Ahsani

M.R.,

Mohammadabadi M.R and Shamsaddini M.B. (2010): Clostridium perfringens isolate typing by multiplex PCR The Journal of Venomous Animals and Toxins including Tropical Diseases 16(4): 573-578

Al Khaldi, S.F., Myers, K.M., Rasooly, A. and Chizhikov, V. (2004): Genotyping of Clostridium perfringens toxins using multiple oligonucleotide microarray hybridization. Mol Cell Probes 18, 359-367.

Albini, S., Brodard, I., Jaussi, A., Wolls chlaeger, N., Frey, J., Miserez, R. and Abril, C. (2008): Real-time multiple $x$ PCR assays for reliable detection of Clostridium perfringens toxin genes in animal isolates. Vet Microbiol 127, 179-185.

Barnes, E.M. (1985): Isolation methods for anaerobes in foods. Int. J. Food. Microbiol. 2(1/2): 81.

$B$ rewere, J. H. and Allgeier, D. L. (1966): Self-contained carbon dioxide hydrogen anaerobic system. Appl. Microbiol. 14: 985-988.

Cohen, N. Ennaji, H. Hassar, M. and Karib, H. (2006): The bacterial quality of red meat and offal in Casablanca (Morocco), Mol. Nutr Food Res., 50 (6): 557-62.

Crespo R.; Fisher, D.J.; Shivaprasad, D.L.; FernandezMiyakawa, M.E. and Uzal F.A. (2007): Toxinotypes of Clostridium perfringens isolated from sick and healthy avian species. J. Vet. Diagn. Invest. 19(3):329-333.

Cruickshank, R. Duguid, J. P. Marmion, B. R. and Swain, R. H. A. (1975): Medical Microbiology, 12 ${ }^{\text {th }}$ ED., Living stone, London, New York.

El-Naenaeey, E. Y. M. (1989): Ocurrence of C.perfringens type A. Ph. D. thesis (Microbiology), Fac. Vet. Med., Zagazig Univ.

Fahim A Shaltout,, et al. (2017): "Isolation of Clostridium perfringens from Meat Samples Obtained from the University Students' Hostel". EC Nutrition 9.3 142-150.

Fayez, M.; Elsohaby, I.; AlMarri, T.; Zidan, K.; Aldoweriej, A.; El-Sergany, Elham; Elmoslemany A. (2020): Genotyping and antimicrobial susceptibility of Clostridium perfringens isolated from dromedary camels, 
pastures and herders. Comparative

FAO/WHO (1983): WHO surveillance programmed for control of food born, Inst. Vet. Med. $2^{\text {nd }}$ report. Berlin.

Fisher D.J.; Miyamoto, K.; Harris on, B.; Sarker, M.R. and McClane, B.A. (2005): Association of beta-2 toxin production with Clostridium perfringens type A human gastrointestinal disease isolates carrying a plasmid enterotoxin gene. Mol. Microbial., 56L747762.

Fratmico, P., Bhunia, A. and Smith, J. (2005): Food borne Pathogens in Microbiology and Molecular Biology, Caister Academic Press, Wymondham, Norfolk, UK., pp.273.

Gamal A. Younis, Mona M. Radwan; Rasha M. Elkenany and Marwa $H$. Elderieny (2018): Detection of alpha toxin and enterotoxins of Clostridium perfringens isolated from minced meat by real time polymerase chain reaction (PCR). African Journal of Microbiology Research. Vol. 12(23), pp. 546-555

Gibbs， P. A. (1971): The incidence of Clostridia in poultry carcasses and poultry processing plants. B. P. S. 12: 101-110.

Gill, $\quad$ C.O., $\quad$ (1998): Microbiological contamination of meat during slaughter and butchering of cattle, sheep and pigs. In: Davies, A.R., Board, R.G. (Eds.). The Microbiology of Meat and poultry, Blackie Academic, London, pp.118-157.

Guran H. S.; Vural A. and Erkan M. E. (2014): The prevalence and molecular typing of Clostridium perfringens in ground beef and sheep meats. J. Verbr. Lebensm. (2014) 9:121128.

Guran, H. S. and Oksuztepe, G. (2013): Detection and typing of clostridium perfringens from retail chicken meat parts. Appl. Microbiol. 57, 77-82.

Hanninen, M.L., (1980): $E$. coli, Y. enterocolitica, C. fetus spp. Jejuni causing food borne disease. A review Soumer Elainl Alkavilet, 86:175.

Hassan, H.S. (1994): Incidence and serotyping of $C$. perfringens among animal slaughtered at Cairo and Giza abattoirs M.V. Sc. Thesis, Meat Hygiene. Fac. Vet. Med, Moshtohour, Zagazig Univ., Benha Branch.

Hedia, I.H.A. (2009): Clostridial species and related organisms in meat and meat products with special reference to keeping quality defects. The degree of Ph.D., Food Control Dept., Benha University.

ICMSF

Commission

International 
Microbiological Specification for Food

(1978):

Microroganism in foods. Univ.

Their significance and methods of enumeration, $2^{\text {nd }}$ Ed., Univ. of Toronto Press, Toronto, Canada.

Khalid A. Alkheraije (2013): Some Characters of $\mathrm{Cl}$. perfringens Isolated from Fresh and Marketed Processed Meat. Vol. 3 No. 2, Article ID: 32839, 5. revised January 15, 2013; accepted February 15, 2013.

Libby, T.A. (1975): Meat Hygiene $4^{\text {th }}$ Ed. Lea and Febiger, Philadelphia, U.S.A.

Lynch M, Painter J, Woodruff $R$, and Braden $C$ (2006): Surveillance for foodbornedisease outbreaks-United States, 1998-2002. Morbid Mortal Wkly Rep 10:1-34

$\begin{array}{lcr}\text { Macfaddin, } & \text { J.W. } & \text { (1980): } \\ \text { Biochemical } & \text { tests } & \text { for } \\ \text { identification } & \text { of } & \text { medical } \\ \text { bacteria. } & \text { Williams } & \text { and } \\ \text { wikkioing Co. USA. } & \end{array}$

Mohamed, E. M.; Iman I. Suelam and Saleh, M. A. (2010): The presence of toxin genes of Clostridium perfringens isolated from camels and humans in Egypt. Veterinarski Arhiv, Vol. 80 No. 3, Izvorni znanstveni članak.

Nasr, M.E.; Shehata, A.A. and Amer, A.H. (2007): Enterotoxigenicity and typing of Clostridium perfringens isolates from some poultry products in Egypt. J. Appl. Sci. Res., 3(12):1804-1808.

Nauerby B.; Pedersen, K. and Massen, M. (2003): Analysis by pulsed -fieldgel electrophoresis of the genetic diversity among Clostridium perfringens isolates from chickens. Vet. Microbial., 94: 257-266.

Phillips, D. Jordan, D. Morriss, S. Jenson. I. and Sumner, J. (2008): A national survey of the microbial. Quality of retail raw meats in Australia. J. Food protect. 71 (6): $1232-6$. Prabhu, N.; Wilfred, R.S.; Naveen, B.R. and Raghunath, B.V. (2013): Molecular characterization of alpha toxin gene of Clostridium perfringens from chicken's meat. Journal of cell and tissue research. Vol. 13(1) 3455-3458.

Sambrook, J. and Russell, D.W. (2001): Molecular cloning a laboratory manual. $3^{\text {rd }}$ ed. Woodbury: Cold spring Harbor Laboratory Press., 2002. P. 1896.

Smith, L. D. S. and Williams, B. L. (1984): The pathogenic anaerobic bacteria. Charles Thomas publisher. USA.

Smith, L.D. S. and Holdeman (1968): The pathogenic anaerobic bacteria. I st Ed.201255. Charles Thomas publisher, USA. 
Wahl E, Rømma S, Granum

PE (2013) A Clostridium perfringens outbreak traced to temperature-abused beef stew, Norway, 2012. Eurosurveillance 18:28.

Widders, P.R. (1995): Controlling microbial contamination on beef and lamb meat during processing. Australian Veterinary Journal, Brunswick, V.72, N.6p.208-211.
Willis, A. T. (1977): Anaerobic bacteriology, Clinical and Laboratory practice. $3^{\text {th }} \mathrm{Ed}$ Butter Worth, London.

Yibar A., Cetin E., Ata Z., Erkose E. and Tayar $M$. (2018): Clostridium perfringens Contamination in Retail Meat and Meat-Based Products in Bursa, Turkey. Foodborne Pathog.;15(4):239-245. 